doi: 10.20396/rfe.v11i3.8658201

\title{
War? Another possible relation between Yugoslavia and its football
}

Gustavo Ruiz da Silva

\begin{abstract}
:
This article aims to indicate another possible comprehension of war and its relations in the Yugoslavian region. Focused on the construction of national identity, this paper uses the post-structuralist theoretical argumentative movement to invert the common logic of interpretation - to which Foucault and Deleuze are used as reference. Knowing this, the problem is how war, interpreted in another way, can build not only national integration, but also a subjective identity through Football.
\end{abstract}

Keywords: Football. Balkans. War.

\section{Résumé:}

Cet article vise à indiquer une autre compréhension possible de la guerre et de ses relations dans la région de Yougoslavie. Centré sur la construction de l'identité nationale, cet article utilise le mouvement argumentatif théorique post-structuraliste pour inverser la logique commune de l'interprétation Foucault et Deleuze y sont utilisés comme référence. Sachant cela, le problème est de savoir comment la guerre, interprétée d'une autre manière, peut construire non seulement une intégration nationale, mais également une identité subjective à travers du football.

Motes Clés: Football. Balkans. Guerre.

\section{ABOUT IDENTITIES.}

Identity is a polysemic concept of multifaceted and even contradictory dimensions. The complexity of identity as a term must be addressed in the social sciences. Identity is linked to recognition, theories, and explanations that seek to combine the relationship between the subject and collective

\footnotetext{
${ }^{1}$ Pontifícia Universidade Católica de São Paulo (PUC-SP); Universidade de São Paulo (USP)
} 
meanings. Thus, identity can be considered a category of analysis, i.e., a theoretical resource that assists in the understanding of a phenomenon.

Social context provides conditions for identity to be constructed and reconstructed since it is never fixed. The concept of "identity" can be used to express the unique construction that the subject makes of itself, built in a relationship with others, endlessly. Or better yet, being built, as it is always evolving and changing throughout life. Thus, knowing the range of possibilities and theoretical approaches there are, this essay aims to treat a perspective of neither absolute nor unique identity but serves as a category of analysis to interpret the object in question.

The (re)construction of identities in the Balkans is being created considering the exclusion of an identity that had once supported the Yugoslav State (FRY). From this perspective, what is called into question is the difference; not the similarities. If before "not being European" united them, now it does not serve as an agglutination anymore. With the dismantling of the USSR, the end of Yugoslavia was a matter of time; following this, the (re)construction of national identities began by considering ethnic groups, about that Woodward (2000, p.11) points out:

In other words, the affirmation of national identity is historically specific. Although the origin of the national identities of the former Yugoslavia can be traced back to the history of the communities that existed within that territory, the conflict between them arises in a particular moment. [...] One of the ways in which identities establish their claim is by appealing to historical antecedents. [...] by reaffirming their supposedly lost identities, searching for them in the past, they may be producing new identities.

Several artifices are used for the construction of national identity, one of them being the constant construction of symbolic signs and aspects, where the use of the symbolic is part of the search for the real domain. The 
identity formation can be constructed by a socially constructed symbolic representation; a representation that incorporates practices of significations and symbolic systems, in which meanings are produced and, therefore, guide subjects.

In the Structuration Theory, agents and structures are determinants to explain social behavior. The structure is the result of social practice, and agents are construct(ed)ors of such practices and structures; it holds ideas, rights, and obligations; they act according to rules, but they maintain their own interests. From this, it is possible to understand society through the relations of its structures and agents.

Intersubjective meanings are not only composed by aggregates of world interpretations but also by a collective knowledge that is shared by those capable to influence practice and social reality, such as agents. Emphasizing the importance of intersubjectivity, comprehending said agent's social practices has become vital. In this manner, the agent's interpretation turns into social reality, as said by Adler (1999, p.211). It can be a collective understanding, a practice, a control, or any structures of knowledge formed and reproduced by members of a society, according to their behavior.

\section{SOME THEORETICAL REFERENCES.}

At the beginning of the 19th century, Carl von Clausewitz defined war by this famous deduction: "war is merely the continuation of policy by other means" (1976, p.87). Clausewitz wished to keep the plant of his theory of war "close to its proper soil experience" (ibidem, p.61) and to maintain a balance between war's violence, creativity, and rationality, "like an object suspended between three magnets" (ibidem, p.89). As said by the author:

[...] war is an act of mutual destruction [...] Like two incompatible elements, armies must continually destroy one another. Like fire and water, they never find themselves in a 
state of equilibrium but must keep on interacting until one of them has completely disappeared. (1976, p. 216)

However, in the middle of the last century, Michel Foucault, intending to provide a historical background to the study of power, concluded that the modern type of power relations can only be understood based on "the necessity of combat and the rules of strategy" (1986, p. 308). Related to Clausewitz, Foucault appears to occupy the opposite end of the spectrum when it comes to analyzing the relationship between war and politics. Foucault is, as said by Deleuze (1986, passim), interested in specific contemporary experiences in their tripartite relation of knowledge, power, and ethics.

For him, victory or defeat in politics "does not obey the law of all or nothing" (Foucault, 1986, p.27); "power should be studied [...] on the basis of that relation itself, insofar as it determines the elements on which it bears" (idem, 1980, p. 15). He conceives power relations as a continuous confrontation of strategies, "a perpetual battle rather than a contract regulating a transaction or a conquest of territory" (idem, 1986, p. 26). It can be summarized in the word: agonism, that means combat, competition, or "a relationship which is at the same time reciprocal incitation and struggle; less of a face-to-face confrontation which paralyzes both sides than a permanent provocation" (idem, 1982, p. 222).

For Foucault (1977. p.151), in this world of war, there is no ultimate sovereign power, nor are there any written or unwritten moral rules and "every power relationship implies, at least in 'potentia', a strategy of struggle or confrontation" (1982, p. 225). Subsequently, it is likely to say that Clausewitz's maxim is reversed, politics are merely the continuation of war by other means.

\section{A BRIEF INTRODUCTION TO THE BALKANS.}


When the word "Balkans" is pronounced in Western Europe, the associations are usually negative: a zone of frequent wars, conflicts, political instability, confusion, economic crisis, violent claims of national or religious identity, left-wing dictatorships, etc. However, many of these images are merely superficial representations, sometimes purposely exaggerated, sometimes equivocal, or reduced to the territory of the former Socialist Federal Republic of Yugoslavia and to the crisis of its disintegration provoked by the civil war between 1991 and 1995 .

Nevertheless, it might be reminded that in this region there are numerous qualifiers, such as geographic, historical, linguistic, political, and economic aspects... What is certain, is that the Balkans is an ethnically and religiously heterogeneous area with large cultural differences, but also with countless similarities in terms of folklore customs, mentality, character, parts of the historical past, ways of thinking, climate, geography, gastronomy, or music.

If it is necessary to define the Balkans in geographical terms, is arguable that the territory between the Adriatic, Ionian, Aegean, and Black seas is considered Balkan. Thus, geographically, the Balkan area would consist of Greece, Bulgaria, Romania, the European part of Turkey, Albania, Macedonia, Serbia, Montenegro, Bosnia and Herzegovina, Croatia, Slovenia, and Kosovo. Under other conditions, because of historical reasons (the Austro-Hungarian occupation), religious (Catholicism heritage), cultural (the Western-like mentality and the use of the Latin alphabet), or politics (the recent accession to the European Union), Croatia and Slovenia often deny any identification with the Balkans, perhaps perceiving these qualifications as negative and derogatory. In this way, integration into the European Union does not diminish the Balkan identity, since Romania and Bulgaria are already part of this institution and can be perfectly characterized as Balkans.

Another stereotype about the Balkans, present in the Western imagination, is that it originates from ex-communist or socialist countries, so often identified with the "Eastern bloc" which emerged in the Cold War. 
However, this characterization is not entirely correct, because the Socialist Federal Republic of Yugoslavia did not belong to this political formation but to the Non-Aligned Movement, strengthening Stalin and Tito differences. Hence why, care must be taken when discussing the Balkans. The Balkans is a region that is anything but homogeneous and uniform as it is made out to be.

\section{RELATIONS BETWEEN POLITICS AND FOOTBALL.}

It is not an unusual hypothesis defending that, as Pimenta (2003, p. 39-55) says, organized cheerleaders can be trained under a militaristic nature or, as Marivoet (1992, p. 137-153) argues, that football is surrounded by an aesthetic of violence or, as Eric Dunning and Norbert Elias point out, that the "game" itself contains elements that can serve as vectors of aggression - about this, there is no doubt that football stirs the passions of its lovers.

In the modern world, football has been consolidated as a significant means of social interaction between peoples and cultures going far beyond the stadiums. Historically, football has been appropriated in the world for the defense of diverse political, economic and/or cultural interests internal and external to the countries. At one hand, the first type of appropriation is a stronger political-identity character, but in most recent transformations it has ascended with globalization movements and involved transnational economic interests as well.

It is common in the national formation the appropriation of the sport by the State as a coercive mechanism in societal constitution to approach the different regions and to standardize practices in all territory. It is also possible to perceive the use of media in the sport's diffusion and make it a factor for the construction of the national identity.

Football, as one of the most popular sports in the world, has continuously developed, specifically aimed at increasing the physical demands and loads to which the soccer players are exposed to during the 
training and competitions. Modern football requires a much faster game, short response time, with less thinking, more demand, and with highly developed cognitive, functional and motor skills course (MARKOVIC; BRADIC, 2008, passim).

As a result of it, people end up mobilizing because of the sport. It was already practiced by a significant portion of the population as a practical and inexpensive means of entertainment, collective integration and physical education. However, in objective terms, sports in the last century have come to be a fundamental characteristic of national identities.

In ancient Yugoslavia, war and reconfigured identities reshaped the feeling of abhorrence exhibited in the Balkans - which reflected in football, that consecutively and actively participated in the conflict - influenced a crucial milestone in the memory of the region reconfiguring the political, geographical and cultural reminiscence of the region and the way it is managed. This relationship between war and sports in ancient Yugoslavia is prominent in the construction of new selves.

Football in the Balkans does not stand by itself as a noumenon, but since the region does not either, as borders and identities are invariably changing, the construction of identities are being formed all the time. Football and the effects it have on the Balkans is unfailingly involved in and it takes part in the changes, but in return also get modified by changes, including the issues and expressions of violence, as part of that society.

Throughout the late 1970s and early 1980s, the football grounds of Yugoslavia became popular places for nationalist recruitment. In May of 1980, the Yugoslav Head of State, Marshal Tito, died, leaving behind no obvious unifying successor. Nationalists, both in Serbia and Croatia, understood how they could use football to further their own ends. Nationalist use of football to further perpetrate violence escalated in tandem with the crumbling of central control.

Subsequently the dissolution of the former Yugoslavia, the stability of the Western Balkans is an important objective of the European Union (henceforth, EU). One of the main strategic objectives of the EU is to 
contribute to stability and good governance in their immediate neighborhood. This commitment, combined with Slovenia's entry into the Union on May 2004 and the recognition of Croatia and Macedonia as candidate countries, encouraged the aspirations of these states in becoming future members of the EU. In devising a policy of conflict prevention and peacebuilding, the Union faced the accession of these countries as the ultimate guarantee of stability in this region.

For example, following its independence in 1991, Macedonia has developed a transition process to replace its system, discredited by conflict and communism, for another that brings stability and security to the country. In this sense, the State has been exposed to the influence of the international community in general and to democratic principles and values encouraged by the EU.

For this group of countries, the European Union represents a legislative framework that promotes regional security and helps to overcome a history of external domination and internal animosity. It equally represents a decisive stimulus to economic and social modernization and the end to a long marginalization on this part of Europe. Finally, it is a better governance guarantee, at least the existence of democratic norms that allow greater control of political elites.

Less than 15 years ago, the Balkans shocked the world with their images of terror, nonetheless, few know today where it is or much less what happens there. This region, now ignored by the news, continues with tangible problems, although expressed in a different manner than fifteen years ago. An analysis of the Balkan War should consider the construction and reconstruction of identities, few of the more prominent identities in the regions there are Muslims Bosnians, Bosnians with Serbian ancestry, Croatian ancestry, etc. There are also identities in the region Slovenes, who are Slavic, and Germanic homogenized, but who have all been Yugoslavs.

There is also the modern country of Albania, consisting of Albania, Romania, and Bulgaria, which has in its Romanian and Bulgarian majority respectively. There is also Macedonia, which never had an ethnic group 
claiming territory, but since General Josip Broz Tito created Macedonia, the Bulgarians, Romanians, Egyptians, Serbs and Albanians who were there were assimilated into the Macedonian identity.

The war has disrupted the normal course of football competitions. Nevertheless, several initiatives taken by different football players will help to rebuild a routine around the practice of the game. From this point of view, to seek to recreate social normality through football is part of an eminently political process although the aims can profoundly diverge (TRÉGOURÈS, 2017, p. 157).

To this, Čolović (cf. 2002) is particularly interested in these values and practices, what Vrcan and Lalić (cf. 1999), and Perasović and Mustapić (cf. 2013) call the subculture of supporters. The author takes us on the path of symbolic and ritualized violence before the match and in the stadium that leads these young men through warrior songs, depreciative and insulting to opponents. Peter Marsh calls this "aggro", to actual violence at the stadium, then to barbaric violence on the battlefield perpetrated against all civilians and children indiscriminately. In the words of Norbert Elias, the football match was a training ground in the war for Belgrade Red Star Delije group supporters, in discipline and rehearsal fan songs that will then be adapted or picked up as they are on the battlefield (TRÉGOURÈS, 2017, p. 186).

The demonstrations of Vrcan and Čolović thus complement each other to give football a natural affinity with violence, war and nationalism. Whether from the top (through a theorization of football as the world), or from below (considering the world of extreme supporters), the two authors converge on the same idea that football and its agents are, by their nature even, parties to the war, and not a mere external object by agents engaged in the exceptional circumstances of the Yugoslav case.

As inferred by Trégourès, what characterizes Yugoslavia, and what is perchance its exceptionality in this specific context, is the extreme politicization of supporters and their political violence, whether it is to fight against an unjust communist regime, or against the rivals of other communities. From then on, being an activist of his cause was often 
equivalent to be a nationalist political activist, even if he had to defend his ideas on the battlefield once the war had begun. In these conditions, is it the football supporter who got devoted to the war?

Supporters' ideological engagement's aspect is an important point to emphasize in order to disqualify the "make a profit" idea. There is no doubt about the ideological aspect of the Croatian fans since, at the time of their commitment, the balance of power was unfavorable to Croatia, so there was no doubt a symbolic reward for the commitment, but no profit in the villainous sense of the term (GRAXIE, 2005, pp. 157-188).

On the Serbian side, the Arkan's Tigers, who were made up of football fans, were particularly known for engaging in all kinds of the underground business. It saw action from mid-1991 to late 1995, initially in the Vukovar region of Croatia. It was supplied and equipped from the reserves of the Serbian police force during the War in Croatia and Bosnia. Their base camp, based in Erdut on the Serbian Croatian border, was strategically located to grow their relations in an internationally struggled FRY. In addition, they were not well paid, which is a reason to arouse interesting vocations.

It is known that The Serb Volunteer Guard, also known as Arkan's Tigers or Arkan's Men, was created on 11 October 1990 by twenty Red Star Belgrade football club's members of the Ultra group Delije Sever. Delije is an umbrella name referring to the supporters of various sports clubs that compete under the Red Star Belgrade Sports Society banner. Though Red Star Sports Society has clubs in over twenty sports, Delije mostly focus on football and basketball. The name Delije first began to be used by hardcore Red Star supporters during the late 1980s. Thus, the Delije, far from leaving the political awareness of nationalism, take instead a place of choice, as legitimate as writers or the church. The songs and slogans popularized in the stadiums coincide with those sung during the mass demonstrations organized by Milošević and his allies in 1988-1989.

Following that, The Guard was under the command of the military in charge of these territories during the first half of the 1990s. According to Christopher Stewart (2009, p.155-169), it was not the fighters who chose the 
Tigers, but the Tigers who chose those who would join them, after an exhausting physical training and unfailing ideological conditioning. In other words, joining the Tigers implied a prior ideological commitment, where indeed other groups, such as the "White Eagles" of Višegrad, led by the young Milan Lukić, were not motivated by heroism, honor, or homeland, but exclusively by profit (SUDETIC, 2001, p. 187).

The world of football has thus contributed to the awareness-raising mechanism for the nationalist cause. It did it in a complementary way to classical emotional entrepreneurs like intellectuals and politicians. Where, with a burst of national pride, the stadiums served to directly promote the nationalist exaltation and hatred of the other, trivializing and calling for the use of violence. Before the conflict erupted, the stadiums had played a very definite role in raising awareness of nationalism - Yugoslavia's symbolically killing. Dissolution does not inevitably lead to war, but inevitably leads to a bellicose climate, as could have been said by Foucault, that no one can escape. It is through very specific events, like these that take place in stadiums, for example, that multiple types of violence are expressed (TRÉGOURÈS, 2017, p. 120).

\section{POSSIBLE CONCLUSIONS.}

To represent this problem, it is possible to analyze this occasion: in the 80s, Red Star supporters, in favor of Serbian nationalism, acted with songs like "Serbia yes, Yugoslavia no". While the Serbian nationalism was controlled in favor of Milošević, other nationalisms were ignited in Yugoslavia; such as the Slovenian, Bosnian and Croatian - the nationalistic sentiment was spreading throughout the region. In the meantime, Serbs and Croats clashed in the streets of Zagreb. This increase in civilian violence was reflected inside the football stadium, as violent offenses have increased also. It set the context for the significant "classic" match of Yugoslavia; the game held in Zagreb engendered the Croatian's Independence War. Before the end of the first half, widespread fighting broke out between Serbs and 
Croats; the Serbian police began to crack down on the Croats. This confusion continued outside the stadium, spreading throughout central Yugoslavia (FOER, 2005, pp. 22-24).

The fascinating nature of both football and the subculture of its supporters shifts the focus to the general theoretical level and supplants the necessary contextualization in the analysis of the role of football in the wars in Yugoslavia. It is thus a question of operating as much a theoretical refocusing as a contextual refocusing in order to try to solve the question of the possible elective affinities between football and the war.

Football, in its rapport with politics, and consequently with war, plays an essential role as an instrument in budding nationalism. It is an infrapolitical force and a category that subliminally produces the identity and cohesion of a people. According to this methodological structure, is possible to argue that this expression, as something parallel and correlational to politics, in its agonistic movement, produces the self-collective-image in its ideological impulse to create change in material existence. Football, politics, and war represent categories that work as one because all of them operate inside of the latter's will - the change of its form does not change its crystallized ambit. The being's subjectivity is created by the skirmish of forces; by the end of the traditional war, something that emerged turned the Balkan identity possible and constantly mutable. Based on that it is possible to say that, even with the institutional peace supported by the EU in the Balkans, the war has never ended, but flowed through other means.

\section{BIBLIOGRAPHY REFERENCES.}

ADLER, E. “O Construtivismo no Estudo das Relações Internacionais”. In: Lua Nova, no.47, p. 201-246.

ČOLOVIĆ, I. The Politics of Symbol in Serbia: Essays in Political Anthropology. London: Hurst, 2002. 
CLAUSEWITZ, C. von. On War. Ed. and transl. M. Howard and P. Paret. Princeton: Princeton University Press, 1976.

DELEUZE, G. Foucault. Paris: Éditions de Minuit, 1986.

FOER, F. Como o futebol explica o mundo: um olhar inesperado sobre a globalização. Rio de Janeiro: Jorge Zahar, 2005.

FOUCAULT, M. "War in the Filigree of Peace: Course Summary", In: Oxford Literary Review, n. 4, v. 2, p. 15-19, 1980.

."The Subject and Power". In: DREYFUS, H. L; RABINOW, P. Michel Foucault: Beyond Structuralism and Hermeneutics. Brighton: Harvester Press, 1982.

. Discipline and Punish: The Birth of the Prison. Hannondsworth: Peregrine Press 1986.

GRAXIE, D. "Rétribution du militantisme et paradoxes de l'action collective”. In: Revue suisse de science politique, n. 11, 2005.

MARIVOET, S. "Violência nos espetáculos de futebol". In: Revista Sociologia Problemas e Práticas, n. 12, p. 137-153, 1992.

MARKOVIC, G.; BRADIC, A. Nogomet: Integralni kondicijski trening. Zagreb, GEA Sport, 2008.

MUELLER, J. "The banality of ethic war". In: International Security, vol. 25, n. 01, 2000.

PERASOVIĆ, B.; MUSTAPIĆ, M. "Football Supporters in the Context of Croatian sociology: Research Perspectives 20 years after". In: Kineziologija, n. 45, v. 2: pp. 262-275, 2013. 
PIMENTA, C. A. M. “Torcidas organizadas de futebol - identidade e identificações, dimensões cotidianas". In: ALABARCES, Pablo (Org.). Futbologías: fútbol, identidad y violencia en América Latina. Buenos Aires: CLACSO, 2003, p. 39-55.

SUDETIĆ, C. "Le criminel de guerre". In OURDAN, R. Après-guerre(s): années 1990, chaos et fragiles espoirs. Paris Autrement, 2001.

STEWART, C. Arkan, la tigre dei Balcani, Padova: Ed. Alet, 2009, pp.155169.

THOMAS, N. The Yugoslav Wars: Bosnia, Kosovo and Macedonia 1992-2001. Osprey Publishing Ltd. Retrieved, 2013.

TODOROVA, Maria. Imagining the Balkans. Oxford, New York, Oxford University Press, Oxford, 1997.

TRÉGOURÈS, L. Jeu en triangle: Football, politique et identités dans l'espace post-yougoslave des années 1980 à nos jours. Science politique. Université du Droit et de la Santé - Lille II, 2017. Français.

VRCAN, S.; LALIĆ, D. "From Ends to Trenches, and Back: Football in the Former Yugoslavia”. In: AMSTRONG, G. AND GIULIANOTTI, R. (eds.). Football Cultures and Identities. London: Palgrave Macmillan, 1999.

WOODWARD, K. "Identidade e diferença: uma introdução conceitual”. In: SILVA, T. T. Identidade e diferença: a perspectiva dos estudos culturais. Petrópolis: Vozes, 2000, p. 7-72. 
Submetido em: 03/02/2020

Aceito em: 24/04/2020

Publicado em: 02/07/2020 